\title{
The Gender Ideological Clash in \\ Globalization: Women, Migration, and the Modernization Bulding Project OF THE PHILIPPINES
}

\author{
Rhacel SALAzAR ParReñas \\ University of California, Davis
}

My article interrogates the local impacts of global economic processes on the socio-cultural geography of the Philippines. I argue that the development of an export-oriented Filipino economy incorporates a gender ideological clash resulting from simultaneously encouraging and discouraging female domesticity. This clash emerges from the economic dependency of the Philippines on women's work outside the home on the one hand, and a longstanding gender ideology that continues to locate women's gender responsibilities inside the home on the other hand. The dependence of the Philippines on remittances from women's migrant domestic work magnifies this clash. My article looks closely at this gender ideological clash caused by working women's paradoxical positioning vis-à-vis the home, addresses why this clash occurs, describes its consequences for relations in the family, and, lastly, links it to a larger discussion of the status of women in globalization.

In the Philippines, the economy depends on the work of women outside the home but at the same time, it must maintain the belief that women belong inside the home. This is the case because the work that women perform outside the home—-work that sustains

This article benefits from the research assistance of Pauline Chu. Parts of this paper draw heavily from my earlier publication Children of Global Migration: Transnational Families and Gendered Woes (Stanford, 2005). 
and provides the economy with its largest sources of foreign currency - encourages the notion of women's domesticity. Such work includes the care work of nurses and nannies and the labor of docile manufacturing production workers in electronics firms run by transnational corporations. The gender ideological clash embodied in the labor market participation of Filipino women-work that is not supplemental but central to the participation of the Philippines in the global economy-is the social phenomenon that I wish to interrogate in this essay.

In so doing, this essay looks at the intersections of the local and the global in the social geography of the Philippines. My analysis takes heed of the suggestion of Gille and O'Riain to study globalization from the lens of "place-making projects that seek to redefine the connections, scales, borders, and character of particular places and particular social orders” (2002: 277), but I further hone my analysis by looking at place-making projects as gendered processes. My examination focuses on gender's constitution in the modernization-building project of the Philippines, specifically its institution of an export-oriented economy. Looking at the constitution of gender in the economic strategy of the Philippines forces us to consider gender's constitution in both local and global processes. Looking at gender reveals a gender ideological clash not just in the (local) work of women but also in the (global) process of the maintenance of an export-oriented economy.

My analysis of gender's constitution in the implementation of an export-oriented economy by the Philippines and its reliance on the work of women responds directly to the model for studying gender in globalization posed by anthropologist Carla Freeman in her critique of the absence of gender analysis in globalization studies. As she asks, "Why have so many of the major treatises of globalization in the social sciences been systematically bereft of gender analysis when we have, by now, so many excellent accounts of global production and global consumption when addressed at the 'local' level” (Freeman, 2001: 1007)? Freeman insists the problem lies in the binary construct of the "global as masculine and local as feminine” (2001: 1009). My discussion shifts from this construction, which implies that gender could solely be observed 
with a focus on local processes and the "small-scale actors" who are "the very fabric of globalization" (Freeman, 2001: 1008-1009). In my discussion, I show that the macro is gendered as much as the micro and that the examination of the gendering of the macro can reveal to us much about the operation of gender in the micro. Both macro and micro as well as the local and global are gendered processes.

In this essay, I will explain how the economic dependence of the Philippines on the work of women simultaneously encourages and discourages the ideology of women's domesticity. As I will establish, the two largest sources of foreign currency for the Philippines-migrant work and electronics manufacturing-depends on the work of women outside the home but only in jobs that, in their performance, maintain the place of women inside the home. In so doing, I establish the constitution of a gender ideological clash in the implementation of an export-oriented economy by the Philippines. Then, I examine the meanings of this clash in terms of gender relations in the Philippines. I illustrate how this clash results not just in the promise of gender's reconstitution but also in a backlash thwarting and limiting the gains made by women in the process of gender's reconstitution.

\section{The Export Oriented Economy of the Philippines}

The export-oriented economy of the Philippines sends mixed messages to women. It tells women to work outside the home but at the same time, it maintains the belief that women's proper place is inside the home. This paradoxical relationship of women vis-àvis the home underlies the participation of the Philippines in the global economy. As the mainstay of the export-oriented economy of the Philippines, the gender paradox underlying women's labor market participation is that which the Philippines relies on to generate sufficient foreign currency to pay for its loans from foreignlending agencies.

Like many "Third World" countries, the Philippines is saddled with loans to foreign lending agencies such as the World Bank, International Monetary Fund, and the Asian Development Bank. 
Loans burden the Philippines with an annual interest of approximately $\$ 2.5$ billion. ${ }^{1}$ From 1970 to 1998 , the Philippines paid $\$ 77.6$ billion in interest and principal to foreign creditors (Diokno-Pascual, 2001). Still the debt of the Philippines has not decreased. Since the country incurred its first debt in 1962, its foreign debt has steadily grown, reaching more than $\$ 52$ billion by 2000 (Diokno-Pascual, 2001; Guzman, 2001).

To pay for these loans the country has had to borrow more loans from the same lending agencies (IBON, 1997). ${ }^{2}$ And to be able to borrow more money in order to pay for its loans, the Philippines has had to secure the seal of approval of the International Monetary Fund and abide by its recommendation for the Philippines to implement an export-oriented economy. As an export-oriented economy, the Philippines must follow three basic policy elements: (1) the expansion of exports (rather than control of imports); (2) free international trade (rather than protectionist policies); and (3) open door for foreign companies (IBON, 1998). Essentially, the emphasis on export-oriented industrialization has pushed the Philippine economy to produce goods for exports, which are dictated by the needs of foreign direct investors from richer countries such as the United States and Japan.

Export-oriented industrialization also requires the labor of women. Notably, women dominate the labor force in the two industries that generate the most foreign currency for the Philippines: export manufacturing production and migrant employment. Targeted for their presumed patience, docility, and natural orientation to detail, women constitute 74 percent of electronics industry workers. Most of these women, nearly 78 percent of them, are younger than 30 years old (McKay 2006: 213; Chant and McIlwaine, 1995). The work of women in electronics manufacturing production amasses more than $\$ 27$ billion per annum in exports for the Philippines (McKay, forthcoming). The largest source of foreign currency for the Philippines is the electronics and semiconductors produced by electronic firms, which account for over 70 percent of Philippine exports (McKay, 2001, 2004). Likewise, migrant employment provides a secure source of foreign currency to the Philippines, which nets at least $\$ 10$ billion per annum from migrant 
remittances. These remittances come from both the labor of men and women, arguably more from the labor of men, ${ }^{3}$ but still a substantial amount of remittances depends on the work of women, as they constitute two-thirds of land-based migrant workers from the Philippines (Parreñas, 2001).

Considering that women's labor provides the nation with its two largest sources of foreign currency, one can claim that Filipino women have achieved tremendous economic power in the Philippines. But this is nothing new. Women have participated in various income generating activities throughout history, for instance, as informal peddlers who subsidize the main subsistence of men, or as agricultural workers who assist men in tilling the soil, and more recently as productive wage earners in dual income households (Eviota, 1992). Yet women have not had much income earning power in the past as they do today. Testament to this newly gained status of women is the recent reference to them as "breadwinners of the nation” (Mission, 1998) and "new economic heroes” (Rafael, 1997).

The reliance of the Philippine export-oriented economy on the work of women as electronics manufacturers and migrant workers strongly suggests the breakdown of the traditional gender division of labor that has historically kept women inside the home. Yet, before we quickly jump to this conclusion, we should look more closely at the types of work that the economy expects of women and the meanings of gender attached to such work. On the surface, the push for women to work outside the home seems to question the ideology of women's domesticity. Yet a closer look will tell us that it also retains this ideology, as the jobs that women do tend to uphold their domesticity-as nimble fingered electronics production workers or as domestic workers or nurses or some other form of care worker. Such jobs retain the assumption of women's natural aptitude for caring and nurturing.

Not surprisingly, women's economic contributions have not freed them of the ideology of women's domesticity. In the Philippines, women still suffer from a severe wage gap and remain stunted by the sex segregation in the labor market. For instance, women on average only earn 39 centavos for every peso earned by men in 
the Philippines, a figure that has not correspondingly increased with the rising demand for women workers both in the domestic and international labor markets (IBON, 2000). They also suffer from a segmented labor market. Despite the increase in their labor market participation, women still mostly perform jobs that merely extend their responsibilities at home or jobs that reflect the domestic characteristics attached to women in the home. This is surely the case in migrant domestic work or assembly line manufacturing production.

We can actually argue that the export-oriented economy of the Philippines does not just question but also maintains the notion of women's domesticity. We can even argue that the Philippines must maintain the ideology of women's domesticity so as to succeed in the global economy. The retention of the ideology of women's domesticity arguably supplies the Philippines with the labor pool it needs to fill the demand for women's low wage labor by more developed nations in the global economy. The ideology of women's domesticity - as it justifies the wage gap and sex segregation in the labor market -helps keep the wages of women lower than those of men in the Philippines and consequently pushes women to respond to the demand for their labor as domestic workers in more developed nations. Teachers and other female professionals are leading the pack of those going abroad to pursue domestic work. ${ }^{4}$ This is not surprising if we think about their low wages compared to men.

The low wages of women also makes the Philippines attractive to foreign companies in search of locales that can offer the lowest overhead costs in the global economy. As Steven McKay noticed in his study of electronics manufacturing firms in the Philippines, "With rising wage rates in northeast Asia, Malaysia, and Singapore, many multinational firms view the Philippines as an ideal site for their relatively complex yet labor-intensive assembly and test manufacturing. From 1994 to 2000, multinationals from the US, Japan, Europe and Asia poured in nearly US $\$ 9$ billion to develop new plants or upgrade existing ones” (2004: 381). Moreover, the ideology of women's domesticity pushes the notion of women as naïve, docile, and less likely to engage in collective organization, which in turn 
makes the Philippines an even more attractive source of manufacturing labor for electronics manufacturing firms. Notably, the notion of their docility also makes Filipino women more attractive as nannies and elderly care workers. Indeed, Filipino women have been stereotyped as naturally suited carers for the elderly and children in richer nations of Asia, Europe, and the Americas.

As the Philippine economy has to rely first and foremost on the labor market participation of women in export-manufacturing and migrant domestic work to generate sufficient foreign currency, the nation promotes the movement of women away from the private sphere. The economy, however, still continues to keep women inside the home by promoting the restriction of their employment within economically devalued jobs that are considered mere extensions of their work in the private domain. As such, the ideology of women's domesticity is not completely eliminated in the state's implementation of an export-oriented economy that has come to increasingly depend on the feminization of labor. On the contrary, it is actually maintained in the implementation of an export-oriented economy.

My discussion of the export-oriented economy of the Philippines and its dependence on the work of women-a dependence created by the demands of advanced capitalist countries-tells us something about how the maintenance of the global economy is a gendered process. We can arguably claim that the Philippines is a gendered feminine nation vis-à-vis other countries in the global economy. Abiding by the structural adjustment mandates imposed by the International Monetary Fund pushes the virtues of docility, subservience, and obedience onto the Philippines, while it emphasizes its weak economic position vis-à-vis other nations. For only by abiding by these externally imposed mandates and opening their borders to marketization, deregulation, privatization, and exportation can the Philippines remain in good standing in the global economic community. In contrast, countries that control and economically benefit from the International Monetary Fund are those that are gendered masculine as these more powerful nations loom over the Philippines and other feminized nations as disciplinary figures enforcing neoliberal principles regardless of whether or not such principles benefit the feminized nations or not. 


\section{The Backlash Against the Feminization of Labor}

So far, I have established the gender ideological clash that underlies the work of women in an export-oriented economy such as that of the Philippines. Now, I will address the social implications of this gender ideological clash on gender relations in the Philippines. This paradox does not bode well for women. As I discussed in the earlier section, it keeps their wages low. In this section, I will show that this paradox has also led to a backlash against the women who provide the Philippines with much foreign currency. Those in electronics manufacturing confront a glass ceiling and those who wish to migrate confront negative public discourse regarding the reconstitution of their household division of labor in migration.

We first witness the backlash against women's emancipation in the gender division of labor in electronics manufacturing firms and the glass ceiling that limits the mobility of women. The ideology of women's domesticity helps justify not just the lower wages of women compared to [or in relation to] men but also the lesser challenges that women face at work. We see this in the case of export-manufacturing employment. The backlash against the feminization of labor is clearly illustrated in the glass ceiling that confronts women in manufacturing employment. Women's dominance in the growing industry of electronics firms suggests the promise of labor market advancement; especially as such firms institute flexible production strategies that utilize the technical skills of its employees. Yet a glass ceiling continues to block the mobility of women. Women find themselves concentrated in jobs as operators. Skilled high-tech manufacturing jobs that involve decisionmaking are usually reserved for men (McKay, 2006). The technological upgrading of jobs in electronics firms has not benefited the women workers that the industry mostly relies upon as management have chosen to extend "traditional associations between masculinity and technology, demonstrating the power and durability of gendered ideologies and frameworks" (McKay, 2006: 211). The issue of the glass ceiling in electronics manufacturing tells us that the increased labor market participation of women and even the economic dependence of the nation on women have not necessar- 
ily signaled a shift in gender ideologies. Women's earning power has not translated to gender empowerment vis-à-vis men in the workplace. Gender's retention overshadows its reconstitution in the segmentation of electronics manufacturing workers.

The retention of gender in women's labor market activities also occurs in the institution of the family. We see this in the families of migrant women whose earning power has not smoothly enabled them to negotiate for more egalitarian relations. This is the case because traditional gender ideologies discourage gender egalitarianism. Headlines on May 26, 1995 from two of the largest circulation newspapers in the Philippines read: "Overseas Employment a Threat to Filipino Families" and "[President] Ramos Says Pinay OCWs [Overseas Contract Workers] Threaten Filipino Families” (Agence France Presse, 1995). In a speech delivered to the Department of Social Welfare on May 25, 1995, President Fidel Ramos had called for initiatives to keep migrant mothers at home. President Ramos stated: "We are not against overseas employment of Filipino women. We are against overseas employment at the cost of family solidarity" (Agence France Presse, 1995). By calling for the return migration of mothers, President Ramos does not necessarily disregard the dependence of the Philippine economy on the foreign remittances of its mostly female migrant workers. However, he does make clear that it would only be morally acceptable for single and childless women to migrate because the migration of mothers comes at the "cost of family solidarity" (Ramos in Agence France Presse, 1995).

Agreeing with President Ramos are media depictions of the migration of mothers and their impacts on the family and well being of children. For instance, media reports often associate the emigration of mothers with the sexual abuse of children. As one newspaper columnist boldly states, "Incest and rapes within blood relatives are alarmingly on the rise not only within Metro Manila but also in the provinces. There are some indications that the absence of mothers who have become OCWs [overseas contract workers] has something to do with the situation" (Toledo, 1993: 4). Although incest is a social problem in the Philippines, its direct correlation to the emigration of mothers is an unproven specula- 
tion. Studies have yet to show that there are higher rates of incest among children of migrant mothers than in other families.

The media's pathological depiction of migrant mothers and their families allude to women's wrongful abandonment of gender traditions. The migration of women supposedly results in the instability of family life and consequently the use of "drugs, gambling and drinking” among children (Fernandez, 1997: 5). Without doubt, sensationalist reports on the well being of children in transnational families fuel the vilification of migrant mothers. Yet in the course of vilifying migrant mothers, news media reports notably leave fathers free of any responsibility for the care of children. The media presumes as it implies that men are naturally incompetent carers of the family. In public discourse, the gender imbalance on who is to blame for the supposed crisis plaguing the families of migrant mothers does not just tell us that the migration of women has not reconstituted gender notions of the family. It also tells us that women suffer from a backlash against their efforts to reconstitute the gender division of labor in the family.

Public discourse in the media does not disagree with mainstream views in the community concerning migrant mothers and the welfare of their families. In the course of my research on the welfare of children of migrant workers in the Philippines, I found that many individuals feel that fathers and not mothers should be those who migrate to economically support the family. A focusgroup discussion I conducted with members of migrant families, for instance, left me stunned by the litany of depressing responses that participants gave concerning the effects of women's migration to the family.

1. They are neglected.

2. Abandoned.

3. No one is there to watch over the children.

4. The attitudes of children change.

5. They swim in vices.

6. The values you like disappear.

7. They take on vices.

8. Men take on mistresses. 
9. Like with the children, when you leave, they are still small, and when you come back, they are much older. But they do not recognize you as their real parents. And what they want, you have to follow. They get used to having a parent abroad and they are used to always having money.

10. That's true. That's true.

These negative sentiments were notably shared to me by members of the families of migrant fathers, who believe that transnational households with migrant fathers are more conducive to establishing a healthy family life than are the families of migrant mothers. These comments reveal to us the staunch retention of gender conservatism concerning the family division of labor in Philippine mainstream society.

\section{The Gender Ideological Stall}

What are the effects of the backlash on the lives of women who produce foreign currency for the Philippine economy? To address this question, I specifically look at the situation of migrant mothers. As I show, this backlash promotes an ideological stall that maintains women's responsibility for the care of the family and thereby creates the social pressure for migrant women to remain responsible for the care of their children even from a distance.

On the basis that migrants usually leave behind other family members upon migration, one can imagine that the migration of women has initiated dramatic changes in household division of labor. In a study of transnational migrant families of Filipino migrant women in Singapore, Maruja Asis, Shirlena Huang and Brenda Yeoh (2004) noticed that women's migration unavoidably facilitated the entry of men into the world of reproductive work. Yet, they did also note that men rarely became full-time caregivers of children. This suggests that while women's migration may indeed force men to do housework, they do not do so to the extent that it frees women, including migrant mothers, of this responsibility. Indicating that women's migration has resulted in the reconstitution of household practices, "housebands" has become a more and more 
common term used to refer to the spouses of women employed overseas who have been left behind with their children in the Philippines (Lan, 2006: 136). Yet, these "housebands" do not completely retreat from the workforce but usually continue to work outside the home. My study of transnational migrant family life in the Philippines shows that the husbands of migrant women still participate in the labor force. Of 69 young adult children of migrant workers who I interviewed in the Philippines, only two report growing up with an unemployed father. Among my 69 interviewees, it was only in the most rare of circumstances did fathers increase their childrearing responsibilities upon the migration of their wives. Usually, it was the complete absence of extended female kin that forced fathers to do so.

Moreover, women's migration has not necessarily resulted in the economic dependence of men, who actually participate in the labor market in far greater numbers than do women-82.4 percent compared to 48.9 percent of women in 1997 (NSCB, 1999: 27). Men's continual participation in the labor market coupled with their higher wages and positions in the domestic labor force contributes to the retention of the ideology of separate spheres and consequently makes it more difficult for migrant women to eliminate the ideology of women's domesticity from their construction as wives and daughters.

Indeed, the ideology of women's domesticity frees men of the responsibility to care for their children. At the same time, it creates pressure for migrant mothers to maintain the responsibility of nurturing their children from a distance. Between 1999 and 2000, I interviewed 30 children of migrant mothers in the Philippines (Parreñas, 2005); and according to these children, fathers left behind with them in the Philippines do not perform much caring work in the family. Generally, fathers do not increase the amount of their household responsibilities in spite of the greater economic contributions of migrant women to the family. This tells us that motheraway transnational families face a "stalled revolution" similar to the one identified by Arlie Hochschild (1989: 12) in the 1980s among dual income earning couples in the United States. Meaning, men do not respond to the increase in women's labor market participa- 
tion by increasing their share of household responsibilities. Likewise, men in the Philippines still expect migrant mothers to nurture their children even from a distance. Moreover, men forego the physical caring responsibilities that migrant mothers surely cannot perform due to their geographical distance by passing this work onto other women in the family (e.g. daughters, domestic workers, or extended kin). None of my interviewees had relied on their father for their primary care as infants. Instead, other women cared for them.

I found that migrant mothers maintain the traditional division of labor in the family upon migration. They do not only reconstitute mothering by providing acts of care from a far, but also often do so by overcompensating for their physical absence and performing a transnational version of what Sharon Hays identifies as "intensive mothering," meaning the work of expending a "tremendous amount of time, energy, and money in raising their children" (Hays, 1996: $x$ ). They attempt to maintain intimacy and struggle to nurture their children from a distance. This means that migrant mothers are responsible for ensuring both the economic and emotional security of their children.

Acts of nurturing across great distances do not only reinforce conventional gender norms, but also heighten the traditional gender expectations of children. Based on the stories of children, migrant mothers tend to overact their performance of gender so as to compensate for their physical absence from the family. The family of college student Benjamin Ledesma, whose mother has worked as a nurse in Saudi Arabia since he was in elementary school, serves as a good example. According to the oldest son Benjamin, his mother acts as a "super mom" both at home and abroad. From afar, she calls on the telephone frequently and is always ready to give advice to her children. Up close, whenever on holiday in the Philippines, she performs mothering even more intensively. She "brings life to the home" by cleaning, serving breakfast in bed, preparing afternoon snacks without fail, and sitting by her children's side as they complete their homework every single day that she spends in the Philippines. As mothers like those of Benjamin nurture so intensively, children easily develop the unrealistic view that mothers 
have a natural inclination to always shower them with acts of love. Thus, children like Benjamin carry the unrealistic expectation that mothers should perpetually be available to meet their domestic and emotional needs.

In addition to the efforts of mothers to maintain constant communication and provide emotional support from afar, children also identified the love of their mothers based on their mother's projection of emotions. Specifically, mothers must abide by "feeling rules" that follow the social order of gender in the family. Coined by Arlie Hochschild, "feeling rules" refer to the direction of emotions guided by social and ideological conventions (2003: 97-100). In this case, mothers must use emotions to counter the threat posed by the distance of time and space against their fulfillment of conventional notions of mothering. The children I interviewed took note of the times when their mothers expressed grief, sorrow, and hardships and used these emotional displays as a way to measure their mother's remorse over her decision to impose geographical distance on their family.

An example is the case of Rudy Montoya, the 19-year-old son of a domestic worker in Hong Kong. He describes:

How would you describe your relationship to your mother? Very close. Because we want to see each other. Even on the phone, she would say that she really wanted to see me. She misses me. She would say that I must be so much bigger now and that she wanted to see how I looked like. I can just tell in the way she talks to me, the way she says it on the phone. She gets very emotional.

Rudy's case is not unusual. Regardless of the division of labor in the transnational family-i.e., whether fathers do housework or not or whether extended kin lend a hand or not-most children I interviewed feel secure over their mother's love based on their mother's projection of grief.

As such, mothers must demonstrate to their children that they suffer while they economically provide for them. For instance, the mother of Floridith Sanchez elicits sympathy from her daughter when describing domestic work in Taiwan as one of continued 
hardship. As Floridith tells me: "My mom told me that she still works even when she is sick. How does that make you feel? I cry. You cry? Out of pity.” Mothers continually remind their children that they struggle a great deal abroad at work. Children often view this as a motive to reciprocate for their struggles. States another daughter of a domestic worker Theresa Bascara: "My inspiration is my mother, because she is the one suffering over there. So the least I can do is do well in school." The image of the martyr mother, one that resonated throughout many of my interviews, shows that children find comfort in their mother's grief over not being able to nurture them directly. This was not true for the children of migrant fathers. For them, emotional security does not mandate an image of a suffering dad. Instead, the view of their father as the "ultimate breadwinner" is enough to give them the security of their father's love. In contrast, mothers cannot only provide material security in order to demonstrate love. To show their affection, migrant mothers must nurture them, care for them, and guide them from a distance, and often they must grieve when doing so. Yet, identifying affection this way fortifies the gender ideology contested by the increased labor market participation of women, thus suggesting to us that the status of women, at least in the export-oriented nation of the Philippines, has not significantly advanced in globalization. This is despite the economic dependence of the nation on the work of women.

\section{Conclusion}

The gender ideological clash that greets the work of women in the Philippines translates to a gender ideological stall similar to the one that has confronted the entrance of women in the U.S. workforce in the last forty years. After all, women still do more housework than do men here in the United States. Yet the Philippines provides us with a more extreme case than does the United States as the Philippines economically depends on women much more than it does on men. Women's work generates more foreign currency than does men's labor. Still, women's economic power has not necessarily translated to gender egalitarianism in society, 
the family, and the workplace, which tells us quite clearly that gender cannot be reduced to economics.

The wall blocking gender egalitarianism in the Philippines does not just speak of a stall but it also suggests society's gender revolt against the advancements of women. In making this point I am not suggesting that women in the Philippines suffer from a more backwards culture than do their counterparts in richer nations. I am instead suggesting that the Philippines is not a passive receptor of the onslaught of changes forced by global capitalism. In this case, global capitalism urges a shift towards the reconstitution of the traditional gender division of labor. But as we can see from the gender ideological stall that faces women in electronics manufacturing firms and migrant women domestic workers, Philippine society has not smoothly accepted the gender transformations engendered by globalization. The co-workers of women in electronics manufacturing firms and the children of migrant domestic workers have rejected such transformations.

Yet, the rejection of gender transformations does not necessarily work to the benefit of the Philippines. The ideology of women's domesticity guarantees the low wages of Filipino women, which in turn allows foreign companies to maximize production and minimize costs. Without doubt, the low wages of Filipino women could only reflect the subordinate position of the Philippines in the global economy or in other words the limited income earning power of the Philippines to generate foreign currency in the global economy.

But why is there a gender revolution against women's emancipation? Is it only because any form of drastic social transformation seems a threat to society? Or is it resistance against the subordinate position of the Philippines in the global economy? If situated in the context of the global economy, the income earning power of Filipino women vis-à-vis men we realize occurs because the export-oriented economy of the Philippines is gendered feminine. The gendering of the Philippines as feminine has led to the nation's reliance on the labor of women outside of the home but only in work that retains their responsibilities inside the home. As I have shown in this essay, this leads to a gender ideological 
clash that has not been well received in Philippine society. Gender conflicts have arisen; resistance against the greater economic power of women has taken place; and gender egalitarianism has not come for women.

This process of conflict, resistance, and rejection over women's labor market participation's reconstitution of gender is significant to our understanding of globalization. It shows us that globalization - the macro system of it-is in itself a gendered process. The masculinization of the transnational professional class in the metropole relies on its feminization of the periphery. Members of the periphery serve them and their families and, simultaneously, create the consumer goods made more affordable to them by the feminized wages of manufacturing workers in the periphery. This gender split between the metropole and the periphery shows us that macro-processes of globalization is as gendered as the local processes that shape people's everyday lives.

\section{Notes}

${ }^{1}$ Personal conversation with Dina Fuentesfina of the Freedom from Debt Coalition, August, 25, 2001.

${ }^{2}$ Recently, the government sought a \$265 million loan from the World Bank and \$300 million from the Asian Development Bank (Guzman, 2001: 17).

${ }^{3}$ According to a survey of overseas Filipino workers, the average cash remittances of men are higher than those of women. In 1995, women remitted an average amount of 19,622 pesos, compared to 32,004 pesos for men, and in 1996, women sent an average annual remittance of 19,389 compared to 33,508 pesos for men (NSCB, 1999: 116). Notably, the disparity between men and women's cash remittances have since grown; men sent twice as much funds to the Philippines from April to September 2002, totaling 45,528,102 pesos compared to the 22,183,752 pesos remitted by women (Republic of the Philippines, 2002). Men consistently remitted more funds than did women regardless of their country of employment.

${ }^{4}$ Notably, the labor shortage spurred by women's labor migration such as in teaching has not led to better working conditions for those professionals and other workers who have chosen not to migrate outside the country. (Ibon, 2000b). 


\section{References}

Agence France Presse. 1995a. "Ramos: Overseas Employment a Threat to Filipino Families,” Philippine Daily Inquirer, 26 May, 11/1. . 1995b. "Ramos Says Pinay OCWs Threaten Filipino Families," Philippine Star, 26 May, 12/1.

Maruja Asis, Shirlena Huang, and Brenda Yeoh, "When the Light of the Home is Abroad: Unskilled Female Migration and the Filipino Family," Singapore Journal of Tropical Geography 25:2 (2004), 198-215.

Bureau of Labor Relations/Department of Labor and Employment. 1999. Labor Management Schemes and Workers' Benefits in the Electronics Industry. Unpublished draft. Manila, Philippines: Bureau of Labor Relations.

Chang, Grace. 2000. Disposable Domestics, Boston, MA: South End Press. Chant, Sylvia and Cathy Mcllwaine. 1995. Women of a Lesser Cost: Female Labour, Foreign Exchange, and Philippine Development. London and East Haven, CT: Pluto Press.

Diokno-Pascual, Maitet. 2001. “The Burdensome Debt.” Unpublished paper available at the Freedom from Debt Coalition. Quezon City, Philippines.

Eviota, Elizabeth. 1992. The Political Economy of Gender: Women and the Sexual Division of Labour in the Philippines. London: Zed Books.

Fernandez, 1997. "Pamilya ng OFWs maraming hirap” (Many hardships in the families of OFWS). Abante (January 27): 5.

Freeman, Carla 2001. "Is Local: Global as Feminine: Masculine? Rethinking the Gender of Globalization,” Signs 26(4): 1007-1037.

Gille, Zsuzsa and Sean O’ Riain. 2002. "Global Ethnography.” Annual Review of Sociology 28: 271-95.

Guzman, Rosario Bella. 2001. "The Economy Under Arroyo: Crisis and Bitter Pills.” Birdtalk: Economic and Political Briefing (July 18): 1-18.

Hays, Sharon. 1996. The Cultural Contradiction of Motherhood, New Haven, CT: Yale University Press.

Hochschild, Arlie with Anne Machung. 1989. The Second Shift, New York: Avon Books.

Hochschild, Arlie. 2003. The Commercialization of Intimate Life: Notes from Home and Work. Berkeley: University of California Press.

IBON, 1997. "In the Cycle of Debt.” People's Policy and Advocacy Studies Special Release (September): 9. . 1998. “The Export Strategy.” Ibon Facts and Figures 23 (21 and 22) (November 15 and 30): 8. 
. 2000. “National Budget: People’s Budget?” Ibon Facts and Figures 23(21 and 22) (November 15 and 30): 2-5 . 2000b. "Teachers of the New Millennium," Ibon Facts and Figures. Volume 23, No 8 (April 30): 2-5.

Lan, Pei-Chia. 2006. Global Cinderellas. Durham, NC: Duke University Press.

Massey, Doreen. 1994. Space, Place, and Gender. Minneapolis, Minnesota: University of Minnesota Press.

McKay, Steven. 2001. "Re-locating Flexible Work Systems: Electronics MNCs In the Philippines.” Philippine Journal of Labor \& Industrial Relations XIX (1).

. 2004. "Securing Commitment in an Insecure World: Workers in Multinational High-Tech Subsidiaries.” Economic and Industrial Democracy 25(3): 375-410. . 2006. "Hard Drives and Glass Ceilings: Gender and Stratification in High-Tech Production.” Gender \& Society 20(2): 207-35.

. Forthcoming. "The Scalar Strategies of Capital, State and Labor in Evolving Philippine Economic Zones.” Journal of Comparative Asian Development.

Mission, Gina. 1998. “The Breadwinners: Female Migrant Workers,” WIN: Women's International Net Issue, 15A (November).

National Commission for the Role of Filipino Women. 1995. Philippine Plan for Gender-Responsive Development, 1995-2025, Manila: National Commission on the Role of Filipino Women.

National Statistical Coordination Board (NSCB). 1999. Women and Men in the Philippines, Makati City: National Statistical Coordination Board.

Parreñas, Rhacel Salazar. 2001. Servants of Globalization: Women, Migration, and Domestic Work, Stanford, CA: Stanford University Press.

. 2005. Children of Global Migration: Transnational Families and Gendered Woes, Stanford, CA: Stanford University Press.

Rafael, Vicente. 1997. “'Your Grief is Our Gossip': Overseas Filipinos and Other Spectral Presences, Public Culture 9: 267-91.

Republic of the Philippines. 2002. 2002 and 2001 Surveys on Overseas Filipinos (Manila, Philippines: National Statistics Office-Income and Employment Statistics Division).

Saskia Sassen. 2003. “Global Cities and Survival Circuits.” Pp. 254-274 in Global Woman, eds. Barbara Ehrenreich and Arlie Hochschild, New York: Metropolitan Books. 
Toledo, Lorie. 1993. “Overseas Job vs. Family Stability.” People’s Journal (December 15): 4. 